\begin{tabular}{|c|} 
Jurnal Keolahragaan \\
Volume 4 - Nomor 1, April 2016, (24 - 33) \\
Tersedia online: http://journal.uny.ac.id/index.php/jolahraga
\end{tabular}

\title{
PENGEMBANGAN MEDIA AUDIO VISUAL DALAM PEMBELAJARAN KETERAMPILAN MOTORIK KASAR PADA ANAK TUNAGRAHITA RINGAN
}

\author{
Michael Johanes. H Louk ${ }^{1)}$, Pamuji Sukoco ${ }^{2)}$ \\ ${ }^{1}$ Universitas Nusa Cendana Kupang, Jalan Adisucipto, Penfui, 85001, Nusa Tenggara Timur, \\ Indonesia. Email: louk_micky@yahoo.co.id \\ ${ }^{2}$ Pendidikan Jasmani, Kesehatan, dan Rekreasi, Universitas Negeri Yogyakarta. Jalan Colombo No. 1, \\ Karangmalang, Yogyakarta 55281, Indonesia. Email: pamujisukoco@yahoo.co.id
}

\begin{abstract}
Abstrak
Penelitian ini bertujuan untuk menghasilkan media audio visual dalam pembelajaran keterampilan motorik kasar pada anak tunagrahita ringan yang layak digunakan. Penelitian pengembangan ini dilakukan dengan langkah-langkah sebagai berikut: (1) pengumpulan informasi, (2) analisis hasil informasi, (3) mengembangkan produk awal, (4) validasi ahli dan revisi, (5) uji coba skala kecil, (6) revisi, (7) uji coba skala besar, (8) revisi akhir, (9) pembuatan produk final, dan (10) diseminasi dan implementasi produk final. Uji coba kelompok kecil dilakukan terhadap enam peserta didik anak tunagrahita ringan di SLB Tunas Kasih 2 Turi. Uji coba kelompok besar dilakukan terhadap sepuluh peserta didik anak tunagrahita ringan di SLB Negeri I Bantul. Instrumen pengumpulan data yang digunakan yaitu: (1) angket para pakar, dan (2) lembar kuesioner praktisi. Teknik analisis data yang digunakan yaitu analisis deskriptif kuantitatif dan deskriptif kualitatif. Penelitian ini menghasilkan media untuk pembelajaran keterampilan motorik kasar pada anak tunagrahita ringan yaitu media pembelajaran keterampilan motorik kasar dengan (1) melompati bentuk, (2) bola panas bola dingin, (3) bola guling kain, (4) bola ringan, (5) menginjak ekor harimau, (6) bola kangguru, dan (7) senam gerak dan lagu.
\end{abstract}

Kata Kunci: pengembangan, media audio visual keterampilan motorik kasar, anak tunagrahita ringan kelas bawah

\section{DEVELOPING AUDIO VISUAL MEDIA TO IMPART THE LEARNING OF BASIC PHYSICAL MOTOR SKILL FOR MENTALLY DEFECTIVE}

\begin{abstract}
This research aims to produce an audio visual media for teaching basic physical motor skill to mentally defective which is appropriate. This developmental research was done following developmental research steps as follows: (1) collecting information, (2) analysing information, (3) developing initial product, (4) experts validation and revision, (5) preliminary field testing, (6) revision, (7) main field testing, (8) final revision, (9) making the final product, and (10) dissemination and implementtation the final product. The small group field testing was conducted to six mentally defective children in SLB Tunas Kasih 2 Turi. The bigger group field testing was conducted to 10 mentally defective children in SLB Negeri I Bantul. The data were analyzed using the quantitative descriptive analysis and qualitative descriptive analysis. The teaching media on physical motor skill consists of seven teaching media on physical motor skill by: (1) Leapfrogging objects, (2) Using hot ball and cold ball, (3) Using fabric bolster ball, (4) Using lightweight ball, (5) Stomping a tiger's tail, (6) Using kangaroo's ball, (7) Calisthenics and song.

Keywords: developing audio video media impart learning physical motor skill mentally defective underaged children

How to Cite Item: Louk, M., \& Sukoco, P. (2016). Pengembangan media audio visual dalam pembelajaran keterampilan motorik kasar pada anak tunagrahita ringan. Jurnal Keolahragaan, 4(1), 24-33. Retrieved fromhttp://journal.uny.ac.id/index.php/jolahraga/article/view/8132
\end{abstract}


Jurnal Keolahragaan 3 (2), September 2015 - 25

Michael Johanes. H Louk, Pamuji Sukoco

\section{PENDAHULUAN}

Pendidikan yang bermutu dalam praktek proses pembelajaran harus dapat memenuhi seluruh kebutuhan peserta didik atau dengan kata lain proses pembelajaran berpusat pada peserta didik. Peserta didik harus merasa nyaman, senang dan tidak tertekan ketika terlibat dalam kegiatan belajar. Pembelajaran harus memberikan makna yang mendalam dan selalu diarahkan untuk tumbuh dan kembang peserta didik, menghargai lingkungan sehingga potensinya dapat berkembang secara optimal. Pendidikan yang bermutu secara fungsional menghantarkan setiap individu untuk mampu bertahan, berdaya saing, secara mandiri dalam kehidupan yang dinamis dan bergerak cepat penuh persaingan.

Di lain pihak praktik-praktik pendidikan khususnya layanan proses pembelajaran yang selama ini banyak dilakukan, baru sebatas pada bagaimana peserta didik dibelajarkan untuk menerima sejumlah materi guna memenuhi tuntutan program dan kurikulum yang telah ditetapkan, di mana program pembelajaran dirancang sesuai dengan jadwal untuk memenuhi target-target yang sarat dan ketat. Daya serap pembelajaran diukur melalui penilaian yang belum sepenuhnya mengukur kompetensi peserta didik.

Layanan pembelajaran belum banyak menyentuh kepentingan peserta didik sebagai pembelajar, layanan pembelajaran belum memenuhi kekhasan serta keberagaman peserta didik, yang berkaitan dengan kondisi fisik, kecerdasan, mental, emosional dan sosial. Padahal layanan pendidikan yang bermutu telah menjadi komitmen, tanggung jawab dan kewajiban pemerintah sekaligus hak setiap warga negara. Kondisi yang digambarkan tersebut menunjukkan adanya kesenjangan antara tuntutan dunia pendidikan yang seharusnya di satu pihak dengan kondisi yang sebenarnya terjadi pada tingkat layanan pendidikan dilain pihak. Kesenjangan ini akan lebih nampak apabila dicermati layanan pembelajaran untuk anak berkebutuhan khusus (ABK) yang mencakup pembelajaran untuk anak tunagrahita.

Anak tunagrahita memerlukan layanan pembelajaran yang mengacu kepada kebutuhan yang khusus karena mempunyai kemampuan atau keterbatasan belajar dan adaptasi sosialnya berada di bawah rata-rata kemampuan anak pada umumnya. Oleh karena itu identifikasi terhadap keadaan anak tunagrahita dipandang perlu guna mengetahui keterbatasannya, dengan mengetahui keterbatasan anak tunagrahita, guru harus dapat melakukan tindakan pembelajaran yang sesuai dengan kebutuhan anak. Menurut Kosasih (2012, p.141) anak tunagrahita yaitu anak yang mempunyai kelainan karena penyimpangan, baik dari segi fisik, mental, intelektual, emosi, sikap maupun perilaku sosial secara signifikan. Hal itu disebabkan adanya kerusakan dalam jaringan susunan saraf pusat yang menyebabkan tidak berfungsinya susunan saraf itu sehingga proses kerjanya tidak berjalan dengan baik.

Pendidikan jasmani untuk anak tunagrahita memerlukan rancangan yang khusus agar kemampuan keterampilan motoriknya mengalami pertumbuhan dan perkembangan yang optimal. Pendidikan jasmani bagi anak tunagrahita harus disesuaikan dengan karakteristik dan kemampuannya, sehingga peserta didik dapat secara aktif mengikuti pembelajaran pendidikan jasmani di sekolah. Selain itu dengan rancangan yang diadaptasikan dengan kebutuhan peserta didik maka pendidikan jasmani bagi anak tunagrahita memberikan makna yang lebih mendalam tidak hanya bermakna sebagai materi pelajaran yang harus diikutinya dan tidak menjadi pelajaran yang sulit diikuti dan membosankan, tapi harus menjadi aktivitas yang menyenangkan.

Salah satu pembelajaran yang menarik untuk anak salah satunya dengan bermain, tidak terkecuali juga dengan anak tunagrahita. Melalui kegiatan bermain anak bisa mencapai perkembangan fisik, intelektual, emosi dan sosial. Perkembangan secara fisik dapat dilihat saat bermain. Perkembangan intelektual bisa dilihat dari kemampuannya mengunakan atau memanfaatkan lingkungannya. Perkembangan emosi dapat dilihat ketika anak merasa senang, marah, menang dan kalah. Perkembangan sosial bisa dilihat dari hubungannya dengan teman sebaya, menolong, antri dalam menunggu permainan dan memperhatikan kepentingan orang lain.

Seiring perkembangan zaman, jenis permainan yang ada pun semakin beragam. Ternyata media audio visual berpengaruh dan bermanfaat bagi perkembangan kemampuan motorik kasar anak seperti berjalan, berlari, melempar, menangkap, melompat, dan meloncat. Ini bisa dibuktikan dengan adanya gerakangerakan dalam media audio visual yang mengarah kepada keterampilan motorik kasar tersebut. Dengan demikian keterampilan motorik kasar sangat diperlukan bagi anak agar mampu melakukan aktivitas secara mandiri. Demikian 
juga dengan anak tunagrahita, anak tunagrahita sangat membutuhkan pengembangan kemampuan motorik kasar agar dapat berfungsi secara optimal.

Oleh karena itu, berdasarkan permasalahan tersebut penulis mencoba menyusun penelitian yang berjudul "Pengembangan Media Aduio Visual dalamPembelajaran Keterampilan Motorik Kasar Anak Tunagrahita Ringan Kelas Bawah."

\section{Anak Tunagrahita Ringan}

Menurut American Psychiatric Association (2013, p.33) anak tunagrahita atau disebut dengan IDD (Intellectual Developmental Disorder) atau gangguan perkembangan intelektual adalah anak yang mengalami gangguan pada masa periode perkembangan yang meliputi intelektual dan keterbatasan fungsi adaptif dalam konseptual, sosial, dan keterampilan adaptif, mempunyai IQ antara 6852 menurut Skala Binet, sedangkan menurut Skala Weschler (WISC) memiliki IQ 69-55 (Somantri, 2012, p.106).

\section{Karakteristik Anak Tunagrahita Ringan}

Menurut Wantah (2007, p.10) bahwa anak yang tergolong retardasi mental ringan atau tunagrahita ringan, adalah anak yang hanya dapat mempelajari keterampilan dan tingkatan akademik sampai kelas 6 Sekolah Dasar (SD). Anak tunagrahita ringan memiliki kemampuan untuk berbicara, tetapi perbendaharaan katakata sangat kurang. Kurangnya perbendaharaan kata mengakibatkan anak tunagrahita ringan mengalami kesulitan untuk berpikir abstrak, tetapi anak tunagrahita ringan dapat mengikuti pendidikan baik di SD maupun di Sekolah Luar Biasa bagian C (SLB/C). Sebagai contoh, anak yang berumur 16 tahun, umur kecerdasan anak tersebut baru mencapai umur kecerdasan setingkat dengan anak yang berumur 12 tahun.

\section{Karakteristik Motorik Anak Tunagrahita Ringan}

Menurut Mumpuniarti (2007, p.17) bahwa karakteristik motorik anak tunagrahita ringan lebih rendah dari anak normal. Karakteristik fisik yang tidak jauh berbeda dengan anak normal ini yang menyebabkan tidak terdeteksi sejak awal sebelum masuk sekolah. Berikut disampaikan adaptasi dalam aktivitas fisik dan kegiatan jasmani anak normal dengan anak tunagrahita ringan (Auxter, Pyfer, Huettig, 2001, p.443).

Tabel 1. Adaptasi dalam Aktivitas Fisik dan

Kegiatan Jasmani Anak Normal dengan Anak Tunagrahita Ringan

\begin{tabular}{|c|c|c|}
\hline $\begin{array}{l}\text { Usia } \\
\text { Kronologi }\end{array}$ & Aktivitas Jasmani Anak Normal & $\begin{array}{c}\text { Aktivitas Jasmani yang dapat dilakukan } \\
\text { Anak tunagrahita ringan }\end{array}$ \\
\hline $\begin{array}{l}4 \text { sampai } 8 \\
\text { tahun }\end{array}$ & $\begin{array}{l}\text { Dapat melakukan aktivitas jasmani/gerak } \\
\text { dasar seperti berjalan, berlari, melompat, } \\
\text { meloncat sebagai rutinitas kegiatan ber- } \\
\text { main tetapi belum terorganisir. }\end{array}$ & $\begin{array}{l}\text { Dalam tahap belajar dan mengalami kesulitan dalam } \\
\text { melakukan aktivitas jasmani/gerak dasar seperti } \\
\text { berlari, melompat, meloncat. }\end{array}$ \\
\hline $\begin{array}{l}8 \text { sampai } \\
12 \text { tahun }\end{array}$ & $\begin{array}{l}\text { Dapat bermain atau melakukan aktivitas } \\
\text { olahraga yang melibatkan memanipulasi } \\
\text { sebuah benda (melempar, menangkap). } \\
\text { Dapat bermain secara kompetisidan dapat } \\
\text { mengikuti peraturan permainan. }\end{array}$ & $\begin{array}{l}\text { Kurang dapat atau masih kesulitan melakukan } \\
\text { gerakan manipulasi sebuah benda (melempar, } \\
\text { menangkap). Dapat mengikuti aktivitas bermain } \\
\text { tetapi dengan arahan yang sederhana. }\end{array}$ \\
\hline $\begin{array}{l}12 \text { sampai } \\
17 \text { tahun }\end{array}$ & $\begin{array}{l}\text { Dapat bermain dengan organisasi yang } \\
\text { tinggi. Dapat mengembangkan keterampil- } \\
\text { an olahraga yang menggunakan raket dan } \\
\text { bola. Dapat berpartisipasi dalam permainan } \\
\text { tim dengan menerapkan strategi dalam } \\
\text { kegiatan kompetitif. }\end{array}$ & $\begin{array}{l}\text { Dapat berpartisipasi dalam kegiatan olahraga yang } \\
\text { dimodifikasi. Lebih efektif dengan olahraga yang } \\
\text { mempunyai sifat individual, karena sedikit } \\
\text { tanggung jawab sosial. Dapat melakukan gerakan } \\
\text { manipulatif (melempar dan menangkap) tetapi sulit } \\
\text { untuk berpartisipasi dalam kegiatan kompetitif. }\end{array}$ \\
\hline $\begin{array}{l}\text { Lebih dari } \\
17 \text { tahun }\end{array}$ & $\begin{array}{l}\text { Dapat berpartisipasi secara mandiri dalam } \\
\text { kegiatan olahraga rekreasi di masyarakat } \\
\text { maupun di pendidikan yang dipilih. }\end{array}$ & $\begin{array}{l}\text { Dapat berpartisipasi dalam olahraga/aktivitas fisik } \\
\text { rekreasi di pendidikan maupun di masyarakat dalam } \\
\text { program-program khusus dan dengan melibatkan } \\
\text { bantuan orang lain. }\end{array}$ \\
\hline
\end{tabular}




\section{Media Pembelajaran.}

Kata media berasal dari bahasa latin medius yang secara harafiah berarti tengah perantara/pengaturan. Dapat diartikan bahwa media merupakan pembawa informasi dari sumber ke penerima. Menurut Smaldino, Lowther \& Russel (2008, p.9). Media adalah alat informasi dan sumber informasi baik berupa alat elektronik maupun non elektronik yang dapat dijadikan sarana penyampaian pesan dalam berkomunikasi. Dalam hal ini pembawa informasi dapat berupa manusia dan benda yang mampu memperjelas informasi sehingga tidak terjadi kesalahan informasi dan diharapkan informasi yang diterima oleh penerima/receiver sesuai dengan sumber. Gerlach \& Ely (Azhar Arsyad, 2002, p.3) juga berpendapat bahwa media secara garis besar adalah manusia, materi, dan kejadian yang membangun kondisi untuk membuat pembelajar mampu memperoleh pengetahuan, keterampilan atau sikap. Dalam pengertian ini, guru, buku teks dan lingkungan sekolah merupakan media secara lebih khusus. Pengertian media dalam proses belajar mengajar cenderung diartikan sebagai alat grafis, elektronika untuk menangkap, memproses, dan menyusun kembali informasi visual.

\section{Nilai dan Manfaat Media Pembelajaran}

Media pembelajaran dapat mempertinggi proses belajar siswa dalam pembelajaran yang pada gilirannya diharapkan dapat mempertinggi hasil belajar yang dicapainya. Ada beberapa alasan mengapa media pembelajaran dapat mempertinggi proses belajar siswa. Pengajaran akan lebih menarik perhatian siswa sehingga dapat menumbuhkan motivasi belajar. Sudjana dan Ravai (2001, p.2) mengemukakan manfaat media pembelajaran dalam proses belajar siswa yaitu: (1) bahan pengajaran akan lebih jelas maknanya sehingga dapat lebih dipahami oleh para siswa dan memungkinkan siswa menguasai tujuan pengajaran lebih baik, (2) metode pengajar akan lebih bervariasi, tidak sematamata komunikasi verbal melalui penuturan kata-kata oleh guru, sehingga tidak bosan, (3) siswa lebih banyak melakukan kegiatan belajar, sebab tidak hanya mendengarkan uraian guru tapi juga aktivitas lain seperti mengamati, melakukan atau mendemonstrasikan suatu hal.

\section{Keterampilan Motorik Kasar}

Menurut Rahyubi (2012, p.211) keterampilan motorik yaitu kemampuan seseorang untuk melakukan suatu tugas gerak secara maksimal sesuai dengan kemampuannya. Keterampilan motorik setiap orang berbeda-beda karena banyak faktor yang mempengaruhinya antara lain minat atau kemauan, usia dan pengalaman. Keterampilan motorik kasar adalah keterampilan gerak atau gerakan tubuh yang memakai otot-otot besar sebagai dasar utama gerakannya. Keterampilan motorik kasar meliputi pola lokomotor (gerakan yang menyebabkan perpindahan tempat) seperti berjalan, berlari, menendang, naik turun tangga, melompat, meloncat dan sebagainya. Juga keterampilan menguasai bola seperti melempar, menendang dan memantulkan bola (Rahyubi, 2012, p.222).

Menurut Lerner \& Kline (2006, p.233) keterampilan motorik kasar melibatkan kemampuan otot-otot besar, seperti leher, lengan, dan kaki. Keterampilan motorik kasar meliputi berjalan, berlari, menangkap, dan melompat. Untuk memberikan rangsangan untuk pengembangan motorik kasar, anak-anak membutuhkan lingkungan yang aman yang bebas dari rintangan, dan membutuhkan banyak dorongan dari orang tua dan guru.

Berdasarkan beberapa pendapat pakar tersebut dapat disimpulkan bahwa motorik kasar adalah keterampilan gerak yang melibatkan otot-otot besar, yang meliputi keterampilan berjalan, berlari, melompat, dan meloncat. Keterampilan motorik dan pengalaman sangat penting bagi pertumbuhan anak, khususnya terhadap anak-anak berkebutuhan khusus, kesulitan dalam koordinasi motorik adalah masalah serius. Beberapa anak menunjukkan perilaku gerak yang khas. Contoh perilaku motorik tersebut adalah gerakan melimpah (ketika anak melakukan gerakan dengan lengan kanan, lengan kiri tanpa sadar melakukan gerakan bayangan), koordinasi yang buruk dalam kegiatan motorik kasar, kesulitan dalam koordinasi motorik halus dan citra tubuh yang buruk. Anak-anak sangat kurang dalam kegiatan pendidikan jasmani.

\section{Gerak Dasar Motorik Kasar pada Anak}

Menurut Lumintuarso (2013, p.34) gerak dasar motorik kasar pada anak memacu kemampuan anak saat beraktivitas dengan menggunakan otot-otot besarnya. Gerak dasar motorik kasar seperti lokomotor, non lokomotor dan manipulatif dapat dijelaskan sebagai berikut: (a) gerak lokomotor adalah aktivitas gerak memindahkan tubuh dari satu tempat ke tempat lain, seperti jalan, lari, lompat, skip, roll, lompat 
tendang kaki, leap; (b) gerak non-lokomotor adalah aktivitas gerak tanpa harus memindahkan tubuh ke tempat lain, seperti mengguncang (shake), mengayun, kontraksi, tekuk, memantul, twist, rebah; dan (c) gerak manipulatif adalah gerak memanipulasi benda, seperti melempar, menangkap, menendang, memukul.

\section{Pendidikan Jasmani Adaptif}

Pada dasarnya pembelajaran adaptif merupakan pembelajaran biasa yang dimodifikasi dan dirancang sedemikian rupa sehingga dapat dipelajari, dilaksanakan, dan diadaptasikan sesuai dengan karakteristik anak berkebutuhan khusus, termasuk di dalamnya yaitu pembelajaran pendidikan jasmani. Dengan pendidikan jasmani adaptif diharapkan anak yang mengalami kebutuhan khusus dapat mengikuti program-program pembelajaran yang akan diajarkan, sehingga akan mencapai tujuan pembelajaran yang diinginkan.

\section{METODE}

\section{Jenis Penelitian}

Penelitian ini merupakan penelitian pengembangan (Research and Development). Menurut Borg, Gall, \& Gall (2003, p.569) penelitian $\mathrm{R} \& \mathrm{D}$ adalah model pengembangan industri di mana penemuan dari penelitiannya digunakan untuk produk-produk dan aturan baru, kemudia dilakukan uji coba lapangan secara sistematis, terevaluasi, dan terstruktur sehingga peneliti menemukan kriteria yang terspesifikasi menurut kefektifan, kualitas, atau standar yang serupa.

\section{Waktu dan Tempat Penelitian}

Uji coba skala kecil dilaksanakan pada bulan Mei 2014 di SLB Tunas Kasih 2 Turi, Sleman dan uji coba skala besar dilaksanakan pada bulan Juni 2014 di SLBN I Bantul, Wates.

\section{Subjek Penelitian}

Subjek coba dalam penelitian pengembangan ini adalah anak tunagrahita ringan. Uji coba skala kecil dilaksanakan di SLB Tunas Kasih 2 Turi, Sleman berjumlah 6 anak dan uji coba skala besar dilaksanakan di SLB SLBN I Bantul, Wates yang berjumlah 14 anak.

\section{Prosedur Penelitian dan Pengembangan}

Menurut Borg Gall, \& Gall (2003, p.784) ada 10 tahap penelitian $R \& D$ adalah sebagai berikut:

\section{Studi Pendahuluan}

Peneliti melakukan kajian awal menganalisis kebutuhan, melakukan pengumpulan informasi lebih lanjut dengan melakukan studi pendahuluan baik dengan cara studi pustaka maupun wawancara langsung dengan guru. Hal yang dilakukan dalam studi pustaka yaitu dengan mengumpulkan bahan mengenai teoriteori, data, dan hasil penelitian yang terkait dengan penelitian ini

Melakukan Analisis terhadap Informasi yang telah Dikumpulkan

Pada tahap ini peneliti mulai menetapkan rancangan model untuk memecahkan masalah yang telah ditemukan pada tahap awal. Hal yang direncanakan antara lain: menetapkan media audio visual dalam pembelajaran, merumuskan tujuan secara bertahap, mengidentifikasi kegiatan-kegiatan yang dilakukan pada setiap tahap penelitian

\section{Pengembangan Draf Awal}

Setelah menganalisis terhadap masalah yang dikumpulkan berdasarkan studi pendahuluan, kemudian dilanjutkan dengan mengembangkan media audio visual dengan menyusun butir-butir instrumen berdasarkan indikator yang telah ditentukan dalam standart kompetensi dasar di dalam kurikulum SLB.

\section{Validasi Draf Awal}

Setelah penyusunan butir tes selesai, dilanjutkan dengan penilaian para ahli materi, yaitu (1) pakar bidang olahraga adaptif, (2) pakar bidang media dan (3) pakar bidang pendidikan jasmani. Pada proses validasi, para ahli materi menilai dan memberi masukan terhadap produk awal. Berdasarkan hal tersebut, dilakukan revisi terhadap produk awal. Proses revisi ini terus dilakukan sampai produk awal mencapai batas nilai tertentu yang telah ditetapkan, yang menunjukkan bahwa produk awal tersebut valid dan layak diujicobakan.

\section{Uji Lapangan Skala Kecil}

Uji lapangan skala kecil dilakukan oleh siswa di SLB Tunas Kasih 2 Turi dan didokumentasikan dalam bentuk Digital Versatile Disc (DVD). Digital Versatile Disc (DVD) ini berisikan pelaksanaan media audio visual dalam pembelajaran keterampilan motorik kasar yang kemudian diobservasi oleh para pakar beserta guru dan ditindaklanjuti dengan proses revisi produk. 
Jurnal Keolahragaan 3 (2), September 2015 - 29

Michael Johanes. H Louk, Pamuji Sukoco

Revisi

Revisi produk yang dilakukan dari hasil uji coba skala kecil, dengan menganalisis kekurangan yang ditemui dalam uji coba skala kecil, masukan yang diterima dari para pakar ditindaklanjuti dengan melakukan revisi produk. Revisi hasil uji coba skala kecil diharapkan menjadi tambahan untuk menghadapi uji coba skala besar.

\section{Uji Lapangan Skala Besar}

Uji lapangan skala besar oleh siswa di SLBN 1 Bantul, Wates. dan didokumentasikan dalam bentuk Digital Versatile Disc (DVD). Digital Versatile Disc (DVD) ini berisikan pelaksanaan media audio visual dalam pembelajaran keterampilan motorik kasar yang kemudian diobservasi oleh para pakar dan ditindaklanjuti dengan proses revisi produk. Proses yang dilakukan pada tahap uji lapangan skala besar serupa dengan proses yang dilakukan pada tahap uji lapangan skala kecil. Hal yang membedakan terletak pada jumlah subjek uji lapangan skala besar yang lebih banyak dari pada uji lapangan skala kecil.

\section{Revisi Akhir}

Proses revisi produk dilakukan untuk mendapat masukan dari para ahli materi agar menghasilkan produk final, langkah ini merupakan penyempurnaan produk yang dikembangkan agar produk akhir lebih akurat. Pada tahap ini sudah didapatkan suatu produk berupa DVD pengembangan media audio visual dalam pembelajaran keterampilan motorik kasar anak tunagrahita ringan kelas bawah.

\section{Pembuatan Produk Final}

Setelah melalui berbagai proses revisi, kemudian dilakukan penyusunan dari hasil pengembangan setelah melakukan uji lapangan skala kecil dan skala besar, yaitu pembuatan produk akhir atau produk final berupa buku pedoman penggunaan dan DVD pembelajaran media audio visual dalam pembelajaran keterampilan motorik kasar anak tunagrahita ringan kelas bawah. Produk final ini yang nantinya akan dipergunakan.

\section{Diseminasi dan Implementasi Produk Final}

Desiminasi produk final yaitu melaporkan produk pada forum ilmiah dalam bentuk ujian tesis. Sedangkan implementasi produk final berupa jurnal yang diterbitkan.

\section{Desain Uji Coba}

Uji coba produk atau draf media audio visual dilakukan sebanyak dua kali, yaitu uji coba skala kecil dan uji coba skala besar. Sebelum dilaksanakan uji coba di lapangan (uji coba skala kecil dan besar), produk penelitian berupa draf media audio visual dalam pembelajaran keterampilan motorik kasar anak tunagrahita ringan kelas bawah. Selanjutnya dimintakan validasi terlebih dahulu kepada para pakar yang telah ditunjuk, dalam tahap tersebut selain validasi para pakar juga akan diberikan penilaian terhadap draf media yang setelah disusun, sehingga akan diketahui apakah media yang disusun layak untuk diujicobakan di lapangan. Kemudian dalam tahap uji coba di lapangan peran dari para pakar adalah untuk mengobservasi kelayakan draf media yang telah disusun dengan kenyataan di lapangan. Setelah uji coba skala luas maka akan menghasilkan sebuah media yang benar-benar valid.

\section{Subjek Coba}

Subjek coba dalam penelitian ini adalah anak-anak tunagrahita ringan di SLB Tunas Kasih 2 Turi Sleman dan SLBN 1 Bantul, Wates. Sesuai dengan tahapan penelitian, maka akan dilaksanakan beberapa tahapan proses pengambilan data. Dalam penelitian ini dilakukan uji coba model di lapangan, yaitu uji coba skala kecil dan uji coba skala besar. Untuk uji coba skala kecil melibatkan 6 anak tunagrahita ringan dan uji coba skala besar melibatkan 14 anak tunagrahita ringan.

\section{Jenis Data}

Jenis data yang diperoleh dalam penelitian dan pengembangan ini yaitu data kualitatif dan data kuantitatif. Data kualitatif berasal dari: (a) hasil wawancara dengan guru SLB, (b) data kekurangan media pembelajaran keterampilan motorik kasar dari ahli materi dan guru pelaku uji coba, dan (c) data masukan ahli materi dan guru pelaku uji coba terhadap media audio visual dalam pembelajaran keterampilan motorik kasar anak tunagrahita ringan kelas bawah. Data kuantitatif diperoleh dari: (a) penilaian ahli materi terhadap media audio visual dalam pembelajaran keterampilan motorik kasar dan (b) penilaian guru terhadap keefektifan media audio visual dalam pembelajaran keterampilan motorik kasar anak tunagrahita ringan kelas bawah. 


\section{Instrumen Pengumpulan Data}

Wawancara

Menurut Riduwan (2011, p.74) menyatakan bahwa wawancara adalah suatu cara pengumpulan data yang digunakan untuk memperoleh informasi langsung dari sumbernya. Wawancara ini digunakan bila ingin mengetahui hal-hal dari responden secara lebih mendalam. Butir-butir pertanyaan tersebut meliputi: (1) pembelajaran keterampilan motorik kasar sudah sesuai dengan kurikulum, (2) seperti apa kegiatan yang diberikan dalam materi pembelajaran pendidikan jasmani, (3) lama waktu pembelajaran pendidikan jasmani, (4) sarana yang dimiliki SLB, (5) peralatan yang digunakan di SLB, (6) kendala yang di alami saat pembelajaran pendidikan jasmani khususnya dalam mengembangkan keterampilan motorik kasar, (7) masalah yang dihadapi oleh peserta didik saat mengikuti pembelajaran pendidikan jasmani, (8) usaha-usaha yang dilakukan oleh guru SLB.

\section{Skala Nilai}

Instrumen pengumpul data kedua yang digunakan yaitu skala nilai. Skala nilai digunakan untuk menilai kelayakan media audio visual dalam pembelajaran keterampilan motorik kasar yang dikembangkan sebelum pelaksanaan uji coba skala kecil, setelah para ahli menilai bahwa media audio visual dalam pembelajaran keterampilan motorik kasar sudah sesuai dengan unsur-unsur dalam skala nilai, media audio visual dalam pembelajaran keterampilan motorik kasar baru dapat diujicobakan dalam uji coba skala kecil. Terdapat tujuh format penilaian untuk masing-masing media audio visual dalam pembelajaran keterampilan motorik kasar, dengan indikator tujuan permainan yang berbeda-beda di dalam setiap permainan. Sistem penilaian dalam format penilaian terdiri dari empat kriteria penilaian yaitu anak dapat melakukan gerakan dengan benar mendapat skor 3, anak dapat melakukan gerakan sendiri tetapi belum sempurna mendapat skor 2, anak dapat melakukan gerakan dengan bantuan mendapatkan skor 1, dan anak tidak dapat melakukan gerakan mendapatkan skor 0 .

\section{Teknik Analisis Data}

Teknik analisis data yang digunakan dalam penelitian ini adalah analisis data deskriptif. Ada dua macam teknik analisis data deskriptif yang dilakukan, yang pertama yaitu analisis data deskriptif kuantitatif, analisis ini dilakukan untuk menganalisis data hasil observasi para ahli pembelajaran penjas, ahli olahraga adaptif, guru dan ahli media terhadap kualitas draf model yang disusun dan dianalisis oleh para ahli sebelum pelaksanaan uji coba di lapangan. Analisis data yang kedua yaitu analisis data deskriptif kualitatif, analisis ini dilakukan terhadap data hasil observasi para ahli pembelajaran penjas, pakar olahraga adaptif, guru dan pakar media dalam memberikan saran ataupun masukan serta revisi terhadap media yang disusun terutama dalam tahap uji coba lapangan baik skala kecil maupun skala besar.

Draf media audio visual dianggap layak untuk diuji cobakan dalam skala kecil apabila ahli materi pembelajaran pendidikan jasmani, olahraga adaptif dan media telah memberi validasi dan menyatakan bahwa semua item klasifikasi dalam skala nilai dinilai "sesuai" dengan memberi tanda centang $(\sqrt{ })$ pada kolom sesuai. Dalam hal ini terdapat lima jenis nilai, yaitu hasil penilaian "sangat baik" mendapat nilai lima (5), hasil penilaian "baik" mendapat nilai empat (4), hasil penilaian "cukup" mendapat nilai tiga (3), hasil penilaian "kurang" mendapat nilai dua (2), dan hasil penilaian "sangat kurang" mendapat nilai nol (1). Jika terdapat para ahli materi berpendapat bahwa item klasifikasi kurang dan sangat kurang (nilai 2 dan 1), maka dilakukan pengkajian ulang terhadap media audio visual yang dapat ditindaklanjuti dengan proses revisi. Untuk data hasil observasi para ahli materi terhadap model permainan, hasil observasi "ya" mendapat nilai satu (1) dan hasil observasi "tidak" mendapat nilai nol (0). Hasil penilaian terhadap item-item observasi dijumlahkan, lalu total nilainya dikonversikan untuk mengetahui berapa kategorinya. Pengkonversian nilai dilakukan dengan mengikuti standart Penilaian Acuan Patokan (PAP). Dalam menginterpretasikan skor mentah menjadi nilai dengan menggunakan pendekatan PAP, yang akan dipaparkan berikut ini (Nurhasan, 2001, p.282).

Tabel 2. Pedoman Konversi Nilai

\begin{tabular}{ccc}
\hline Skor Nilai & Kategori & Keterangan \\
\hline $182-216$ & 5 & Sangat Baik \\
$147-181$ & 4 & Baik \\
$112-146$ & 3 & Cukup \\
$77-111$ & 2 & Kurang \\
$42-76$ & 1 & Kurang Sekali \\
\hline
\end{tabular}


Jurnal Keolahragaan 3 (2), September 2015 - 31

Michael Johanes. H Louk, Pamuji Sukoco

\section{HASIL DAN PEMBAHASAN}

Penelitian ini terdapat 7 media audio visual dalam pembelajaran keterampilan motorik kasar yang dikembangkan antara lain: (1) melompati bentuk, (2) bola panas bola dingin, (3) bola guling kain, (4) bola ringan, (5) menginjak ekor harimau, (6) permainan bola kangguru, (7) senam gerak dan lagu.

\section{Skala Kecil}

Melompati Bentuk

Berdasarkan data hasil observasi media audio visual, menurut penilaian para ahli pembelajaran pendidikan jasmani, ahli olahraga adapted dan guru bahwa media pembelajaran keterampilan motorik kasar dengan melompati bentuk menunjukkan rentang nilai 204-242 dari 205 termasuk dalam kategori sangat baik. Kemudian berdasarkan lembar format penilaian efektifitas media, bahwa media pembelajaran keterampilan motorik kasar dengan melompati bentuk menunjukkan rentang nilai 130-152 dari 130 termasuk dalam kategori sangat baik.

\section{Bola Panas Bola Dingin}

Berdasarkan data hasil observasi permainan, menurut penilaian para ahli pembelajaran pendidikan jasmani, ahli olahraga adapted dan guru bahwa media pembelajaran keterampilan motorik kasar dengan bola panas bola dingin menunjukkan rentang nilai 204-242 dari 206 termasuk dalam kategori sangat baik. Kemudian berdasarkan lembar format penilaian efektifitas media, bahwa media pembelajaran keterampilan motorik kasar dengan bola panas bola dingin menunjukkan rentang nilai 130-152 dari 133 termasuk dalam kategori sangat baik.

\section{Bola Guling Kain}

Berdasarkan data hasil observasi permainan, menurut penilaian para ahli pembelajaran pendidikan jasmani, ahli olahraga adapted dan guru bahwa media pembelajaran keterampilan motorik kasar dengan bola guling kain menunjukkan rentang nilai 204-242 dari 205 termasuk dalam kategori sangat baik. Kemudian berdasarkan lembar format penilaian efektifitas media, bahwa media pembelajaran keterampilan motorik kasar dengan bola guling kain menunjukkan rentang nilai 130-152 dari 134 termasuk dalam kategori sangat baik.

\section{Bola Ringan}

Berdasarkan data hasil observasi permainan, menurut penilaian para ahli pembelajaran pendidikan jasmani, ahli olahraga adapted dan guru bahwa media pembelajaran keterampilan motorik kasar dengan bola ringan menunjukkan rentang nilai 204-242 dari 205 termasuk dalam kategori sangat baik. Kemudian berdasarkan lembar format penilaian efektifitas media, media pembelajaran keterampilan motorik kasar dengan bola ringan menunjukkan rentang nilai130-152 dari 133 termasuk dalam kategori sangat baik.

\section{Menginjak Ekor Harimau}

Berdasarkan data hasil observasi permainan, menurut penilaian para ahli pembelajaran pendidikan jasmani, ahli olahraga adapted dan guru bahwa media pembelajaran keterampilan motorik kasar dengan menginjak ekor harimau menunjukkan rentang nilai 204-242 dari 205 termasuk dalam kategori sangat baik. Kemudian berdasarkan lembar format penilaian efektifitas media, bahwa media pembelajaran keterampilan motorik kasar dengan menginjak ekor harimau menunjukkan rentang nilai 130-152 dari 133 termasuk dalam kategori sangat baik.

\section{Bola Kangguru}

Berdasarkan data hasil observasi permainan, menurut penilaian para ahli pembelajaran pendidikan jasmani, ahli olahraga adapted dan guru bahwa media pembelajaran keterampilan motorik kasar dengan bola kangguru menunjukkan rentang nilai 204-242 dari 205 termasuk dalam kategori sangat baik. Kemudian berdasarkan lembar format penilaian efektifitas media, bahwa media pembelajaran keterampilan motorik kasar dengan bola kangguru menunjukkan rentang nilai 130-152dari 133 termasuk dalam kategori sangat baik.

\section{Senam Gerak dan Lagu}

Berdasarkan data hasil observasi permainan, menurut penilaian para ahli pembelajaran pendidikan jasmani, ahli olahraga adapted dan guru bahwa media pembelajaran keterampilan motorik kasar dengan senam gerak dan lagu menunjukkan rentang nilai 204-242 dari 205 termasuk dalam kategori sangat baik. Kemudian berdasarkan lembar format penilaian efektifitas media, bahwa media pembelajaran keterampilan motorik kasar dengan senam gerak dan lagu menunjukkan rentang nilai 130-152 dari 133 termasuk dalam kategori sangat baik. 


\section{Skala Besar}

Melompati Bentuk

Berdasarkan data hasil observasi media audio visual, menurut penilaian para ahli pembelajaran pendidikan jasmani, ahli olahraga adapted dan guru bahwa media pembelajaran keterampilan motorik kasar dengan melompati bentuk menunjukkan rentang nilai 204-242 dari 237 termasuk dalam kategori sangat baik. Kemudian berdasarkan lembar format penilaian efektifitas media, bahwa media pembelajaran keterampilan motorik kasar dengan melompati bentuk menunjukkan rentang nilai 130-152 dari 130 termasuk dalam kategori sangat baik.

\section{Bola Panas Bola Dingin}

Berdasarkan data hasil observasi permainan, menurut penilaian para ahli pembelajaran pendidikan jasmani, ahli olahraga adapted dan guru bahwa media pembelajaran keterampilan motorik kasar dengan bola panas bola dingin menunjukkan rentang nilai 204-242 dari 240 termasuk dalam kategori sangat baik. Kemudian berdasarkan lembar format penilaian efektifitas media, bahwa media pembelajaran keterampilan motorik kasar dengan bola panas bola dingin menunjukkan rentang nilai 130-152 dari 133 termasuk dalam kategori sangat baik.

\section{Bola Guling Kain}

Berdasarkan data hasil observasi permainan, menurut penilaian para ahli pembelajaran pendidikan jasmani, ahli olahraga adapted dan guru bahwa media pembelajaran keterampilan motorik kasar dengan bola guling kain menunjukkan rentang nilai 204-242 dari 238 termasuk dalam kategori sangat baik. Kemudian berdasarkan lembar format penilaian efektifitas media, bahwa media pembelajaran keterampilan motorik kasar dengan bola guling kain menunjukkan rentang nilai 130-152 dari 134 termasuk dalam kategori sangat baik.

\section{Bola Ringan}

Berdasarkan data hasil observasi permainan, menurut penilaian para ahli pembelajaran pendidikan jasmani, ahli olahraga adapted dan guru bahwa media pembelajaran keterampilan motorik kasar dengan bola ringan menunjukkan rentang nilai 204-242 dari 234 termasuk dalam kategori sangat baik. Kemudian berdasarkan lembar format penilaian efektifitas media, media pembelajaran keterampilan motorik kasar dengan bola ringan menunjukkan rentang nilai130-152 dari 133 termasuk dalam kategori sangat baik.

\section{Menginjak Ekor Harimau}

Berdasarkan data hasil observasi permainan, menurut penilaian para ahli pembelajaran pendidikan jasmani, ahli olahraga adapted dan guru bahwa media pembelajaran keterampilan motorik kasar dengan menginjak ekor harimau menunjukkan rentang nilai 204-242 dari 240 termasuk dalam kategori sangat baik. Kemudian berdasarkan lembar format penilaian efektifitas media, bahwa media pembelajaran keterampilan motorik kasar dengan menginjak ekor harimau menunjukkan rentang nilai 130-152 dari 133 termasuk dalam kategori sangat baik.

\section{Bola Kangguru}

Berdasarkan data hasil observasi permainan, menurut penilaian para ahli pembelajaran pendidikan jasmani, ahli olahraga adapted dan guru bahwa media pembelajaran keterampilan motorik kasar dengan bola kangguru menunjukkan rentang nilai 204-242 dari 241 termasuk dalam kategori sangat baik. Kemudian berdasarkan lembar format penilaian efektifitas media, bahwa media pembelajaran keterampilan motorik kasar dengan bola kangguru menunjukkan rentang nilai 130-152dari 133 termasuk dalam kategori sangat baik.

\section{Senam Gerak dan Lagu}

Berdasarkan data hasil observasi permainan, menurut penilaian para ahli pembelajaran pendidikan jasmani, ahli olahraga adapted dan guru bahwa media pembelajaran keterampilan motorik kasar dengan senam gerak dan lagu menunjukkan rentang nilai 204-242 dari 239 termasuk dalam kategori sangat baik. Kemudian berdasarkan lembar format penilaian efektifitas media, bahwa media pembelajaran keterampilan motorik kasar dengan senam gerak dan lagu menunjukkan rentang nilai 130-152 dari 133 termasuk dalam kategori sangat baik.

\section{SIMPULAN DAN SARAN}

\section{Simpulan}

Dari hasil penilaian para ahli materi dan guru terhadap media audio visual dalam pembelajaran keterampilan motorik kasar yang dikembangkan dapat disimpulkan bahwa media audio visual dalam pembelajaran keterampilan motorik kasar anak tunagrahita ringan kelas bawah ini sangat baik dan efektif. Oleh karena itu, media pembalajaran yang dikembangkan ini 
layak untuk digunakan dan diterapkan dalam pembelajaran pendidikan jasmani untuk anak tunagrahita ringan.

Produk dari penelitian pengembangan ini yaitu buku pedoman penggunaan dan DVD pembelajaran, media audio visual dalam pembelajaran keterampilan motorik kasar anak tunagrahita ringan kelas bawah, yang terdiri dari 7 model permainan, yaitu: (1) melompati bentuk, (2) bola panas bola dingin, (3) bola guling kain, (4) bola ringan, (5) menginjak ekor harimau, (6) bola kangguru, dan (7) senam gerak dan lagu.

\section{Saran}

Saran Pemanfaatan

Saran pemanfaatan berdasarkan penelitian pengembangan yaitu agar media audio visual dalam pembelajaran keterampilan motorik kasar yang dikembangkan dapat digunakan guru sebagai salah satu bentuk pembelajaran motorik kasar pada anak tunagrahita ringan, untuk dapat mewujudkan hal tersebut perlu ditingkatkan kemauan dan kesediaan guru untuk senantiasa meningkatkan kualitas pembelajaran dengan berbagai bentuk pembelajaran yang dapat meningkatkan minat dan kualitas peserta didik dalam belajar, meskipun hal tersebut berarti menambah kesibukan guru dalam menyiapkan bahan-bahan pembelajaran.

Diseminasi

Diseminasi hasil penelitian pengembangan ini dapat dilakukan melalui seminar-seminar, pembuatan artikel, atau dapat juga dilakukan melalui penelitian tindakan kelas dengan melibatkan guru SLB untuk mengetahui efek nyata dari produk pengembangan media audio visual dalam pembelajaran keterampilan motorik kasar.

Pengembangan Produk Lebih Lanjut

Untuk pengembangan produk lebih lanjut perlu dilakukan penelitian yang melibatkan subjek coba lebih besar dan cakupan tempat uji coba yang lebih luas.

\section{DAFTAR PUSTAKA}

American Psychiatric Association. (2013). Diagnostic and statistical manual of mental disorder (5th ed.). Washington, DC: American Psychiatric Publising.
Auxter, D., Pyfer, J., \& Huettig, C. (2001). Principles and methods of adapted physical education and recreation (9th ed.). New York: Mc Graw-Hill.

Borg, W.R., Gall, J.P., \& Gall, M.D. (2003). Educational research an introduction (7th ed.). New York: Longman.

Kosasih, E. (2012). Cara bijak memahami anak berkebutuhan khusus. Bandung: Yrama Widya.

Lerner, J.W \& Kline, F. (2006). Learning disabilities and related disorders characteristics and teaching strategies (10th ed.). New York: Houghton Mifflin Company.

Lumintuarso, R. (2013). Pembinaan multilateral bagi atlet pemula. UNY Press.

Mumpuniarti. (2007). Pembelajaran akademik bagi tunagrahita. Yogyakarta: FIPUNY.

Nurhasan. (2001). Tes dan pengukuran dalam pendidikan jasmani: prinsip-prinsip dan penerapannya. Jakarta: Departemen Pendidikan Nasional.

Oliver, M.A.J. \& Williams, E.E (2005) Vol 2, No 2. Theacing the mentally handicapped child: challenges teachers are facing. Diambil pada tanggal 20 Mei 2013, dari www.internationaljournalofspecialeduc ation.com

Rahyubi, H. (2012). Teori-teori belajar dan aplikasi pembelajaran motorik deskripsi dan tinjauan kritis. Bandung: Nusa Media.

Riduwan. (2011). Skala pengukuran variabelvariabel penelitian. Bandung: Alfabeta.

Sudjana, N. (2001). Penilaian hasil proses belajar mengajar. Bandung: PT. Remaja Rosdakarya.

Somantri, S. (2012). Psikologi anak luar biasa, (cetakan ke 4). Bandung: Refika Aditama.

Wantah, M.J. (2007). Pengembangan kemandirian anak tunagrahita mampu latih. Jakarta: Depdiknas. 